\title{
Early Blight Control in Potato Using Disease-Orientated Threshold Values
}

\author{
J. H. Leiminger and H. Hausladen, Lehrstuhl für Phytopathologie, Technische Universität München, 85350 Freising-Weihenstephan, \\ Germany
}

\begin{abstract}
Leiminger, J. H., and Hausladen, H. 2012. Early blight control in potato using disease-orientated threshold values. Plant Dis. 96:124-130.

Epidemics of early blight caused by Alternaria spp. can cause significant economic damage to potato production if not adequately controlled. In order to improve control of Alternaria spp. in potato, studies were conducted to identify the optimal fungicide strategy and, if possible, to reduce the number of fungicide applications per growing season. Therefore, a disease-threshold-based framework was tested to define the optimal timing of fungicide application. The initiation and subsequent applications of fungicides were based on increases in dis-

ease incidence or severity. Adequate disease control was achieved by a three-time application with azoxystrobin, given that the applications were carried out at pivotal times in the epidemic. Targeted applications of fungicides reduced the number of sprayings required to protect starch yield. Results indicate that early blight can be effectively managed by using fungicide application thresholds based on disease progress.
\end{abstract}

Potato (Solanum tuberosum L.) is a major agricultural product worldwide and play an important role in German agriculture. In 2010, German potato production exceeded 10 million tons, produced on approximately 263,000 ha (41). Potato production may be constrained by diseases and pests and requires intensive use of pesticides. Along with the devastating potato disease late blight (LB), caused by Phytophthora infestans (Mont.) de Bary, potato early blight (EB) is also recognized as one of the most important fungal diseases of potato $(6,7,25)$. EB is caused by Alternaria solani (Ellis \& G. Martin) L.R. Jones \& Grout and A. alternata (Fr.) Keissl., which is also the causal agent for brown spot. EB threatens potato production annually. It can be found in many potato-growing regions of the world, because Alternaria spp. are distributed over a wide range of climatic conditions (32). In addition to potato, tomato (Lycopersicon esculentum Mill.) and other members of the Solanaceae family can be heavily infected. EB mainly affects the potato foliage and leads to leaf necrosis and premature defoliation. Symptoms include characteristic "target-like" lesions of concentric rings that appear dark and sunken and become papery. Lesions enlarge, coalesce, and cause leaf death (29). High temperatures and humidity during the growing season are conducive to disease development and, hence, EB is particularly prevalent in tropical and temperate zones. EB represents a risk to crop production and results in significant yield losses $(32,40)$. When LB is absent, EB is the principal defoliation disease of potato in the northern United States (39). Losses result from reduced photosynthetic area and loss of weakened foliage. In the United States, potato yield can be reduced by up to $30 \%$ due to severe EB epidemics $(9,18,22,36)$. In Brazil, EB is also one of the primary limiting factors for potato production (30). In South Africa, EB has been shown to cause yield losses of 20 to $50 \%$ if not adequately controlled (24). In recent years, EB has become a noticeable problem for German potato production, and a rapid increase in disease severity has been observed in German potato-growing areas (23). Due to its high adaptability, EB has the potential to become a serious threat for potato cultivation in Germany, with yield losses similar to those caused by LB (19). According to Pelletier and Fry (27), several factors might contribute to this situation, including the widespread

Corresponding author: J. Leiminger, E-mail: j.leiminger@web.de

Accepted for publication 26 August 2011.

http://dx.doi.org/10.1094/PDIS-05-11-0431

(C) 2012 The American Phytopathological Society use of susceptible cultivars, the widespread use of the fungicide metalaxyl, which does not control EB, and the application of fungicides according to decision rules designed for management of LB only. As a result of this, EB is the focus of future integrated pest management. To suppress EB and to prevent the losses it causes, potato fields are intensively sprayed with fungicides $(1,11,17,18)$. Fungicides of various chemical groups are currently used in Germany to control Alternaria spp. in potato. Until recently, only protectant fungicides were available for the suppression of Alternaria spp., among them fungicides of the carbamate group (e.g., mancozeb and maneb) as well as the chloronitrile (syn. phthalonitriles) fungicide chlorothalonil. Because of the present approval of active ingredients at the European level (ANNEX I), future registration of mancozeb is questionable. Fungicides such as azoxystrobin (a methoxyacrylate strobilurin) or boscalid (a pyridine carboxamide) in mixture with pyraclostrobin (a methoxycarbamate strobilurin) have been registered recently for control of EB. These fungicides have been available for application on potato against Alternaria spp. since 2007 and 2008, respectively. However, optimization of fungicide use on potato for the management of EB is still a considerable challenge. EB is difficult to control because of its capacity to produce huge amounts of secondary inoculum $(6,26)$. In order to properly control EB, many farmers use fungicides frequently from early in the growing season until vine desiccation $(6,10,13,37)$. Because fungicides are applied regardless of existing disease levels or disease-favorable weather conditions, this strategy may result in superfluous or ineffective fungicide applications. Several investigations have been carried out to improve EB disease management and to reduce the number of sprays $(12,38,40)$. Decision support systems are used in some countries in order to manage EB $(16,33,35)$. In these systems, disease management is based on forecasting favorable weather for infection by Alternaria spp., or temperature degree-day thresholds. Alternatively, fungicide application is recommended depending on plant development (e.g., plant size or the onset of potato flowering; 32). However, prevailing disease progress is not considered.

There is a high risk of selecting fungicide resistance in target populations of Alternaria spp. (26). This causes concerns about ineffective fungicide usage and indicates a requirement for guidelines for plant protection against EB which integrate the actual demand for fungicides. Up to now, no pest management strategy against EB integrates initiation of spraying according to diseasedependent thresholds.

The aim of this work was to incorporate a reduced fungicide strategy into EB management and to combine methods to reduce fungicide usage in potato. Criteria to optimize the timing of fungi- 
cide applications against EB have not yet been established for potato in Germany, nor have studies examined the effectiveness of varying threshold values on control of EB disease. Therefore, spraying strategies were evaluated according to thresholds based on disease progress. For this, fungicide treatments were adapted to the actual epidemic in the field. Targeted applications at particular times of the disease progress led to effective control of EB and protection of starch yield. This may allow for a reduction in the number of sprayings per season and, thus, will benefit the producer, consumer, and environment.

\section{Materials and Methods}

Fungicide field trials-spray program trials. Field trials were carried out in 2005 through 2007 at Gundhöring near Straubing in Bavaria, Germany, which is located in one of the main potatogrowing areas. Trials were designed as a randomized complete block and were replicated four times. Field plots consisted of four rows $\left(0.75 \mathrm{~m}\right.$ between rows) and were $8 \mathrm{~m}$ long $\left(24 \mathrm{~m}^{2}\right)$. Plant density was 40,000 plants $\mathrm{ha}^{-1}$. Trials were carried out using the potato 'Kuras' (Europlant). Kuras is a late-maturing starch cultivar, which is highly susceptible to EB. All plots were fertilized and cultivated according to general agricultural practice. Experimental plots were situated within a commercial potato field which stayed untreated against EB, thus providing natural EB inoculum for disease development. Field trials were all naturally infected by EB. Spore isolation and microscopic analysis showed that, at this location, A. solani was identified as the predominant species. However, A. alternata also could be isolated out of infected leaves in all years and throughout the season (data not shown). Field data (time of planting, flowering, and tuber harvesting) for each year are shown in Table 1.

Implementation of control threshold values. Fungicide treatments were applied depending on disease incidence and disease progress after exceeding threshold values. Chosen thresholds corresponded with certain stages of the disease progress and were assessed as disease incidence (DI) or disease severity (DS). They formed the basis for the timing of fungicide sprays, in order to optimize the control of Alternaria spp. Applications at early stages of disease development were compared with sprays during the progress of an EB epidemic. Fungicide trials included a fully untreated control, an LB-free variant with unrestricted development of EB (EB control), and treated plots for comparing disease severity and yield response. The appropriate timing of the investigated control thresholds was determined following the EB development in the EB control plot. Different threshold values were evaluated with regard to their efficiency of disease control and reduction of yield loss. As variants of a threshold-based disease control, five different (consecutive) stages of EB development were initially selected in 2005: initial application was started at $50 \% \mathrm{DI}_{\mathrm{p}}(50 \%$ of plants showing EB symptoms at any leaf section), $100 \% \mathrm{DI}_{\mathrm{p}}$ (100\% of plants showing EB symptoms at any leaf section), $1 \%$
$\mathrm{DS}_{\mathrm{p}}\left(1 \%\right.$ of the plant leaf area necrotized), $5 \% \mathrm{DS}_{\mathrm{p}}(5 \%$ of the plant leaf area necrotized), and $25 \% \operatorname{DS}_{\mathrm{p}}(25 \%$ of the plant leaf area necrotized). The disease threshold values tested in 2005 were replaced by the threshold values of $100 \% \mathrm{DI}_{\mathrm{m} .1 \text {. }}(100 \%$ of plants showing EB symptoms at the middle leaf [m.l.] section) and $1 \%$ $\operatorname{DS}_{\text {u.l. }}$ ( $1 \%$ of the upper leaf [u.l.] area necrotized), because they were easier to observe in the field. EB-specific treatments were applied alone, at one specific threshold, and were compared with EB-untreated plots in terms of their effect on disease control and reduction of yield loss. Additional applications were carried out at different threshold values. The combination of thresholds, which were chosen at designated stages of disease development, resulted in fungicide double (two EB-specific applications) or triple (three EB-specific applications) treatments. Additionally, fixed-date double treatments applied 6 and 7 weeks after crop emergence and non-threshold-based weekly applications of azoxystrobin or mancozeb were used for comparison.

The evaluations of selected thresholds were conducted with the active ingredient azoxystrobin, which is highly effective against EB pathogens and which has eradicant, protectant, translaminar, and systemic properties (4). Azoxystrobin was applied according to recommended dose rates with $125 \mathrm{~g}$ active ingredient (a.i.) $\mathrm{ha}^{-1}$ (Ortiva $0.51 \mathrm{ha}^{-1}$ ). The active ingredient mancozeb was integrated as a standard treatment and was applied at a dose of $1.350 \mathrm{~g}$ a.i. $\mathrm{ha}^{-1}$ (Dithane Neo Tec, $1.8 \mathrm{~kg} \mathrm{ha}^{-1}$ ). Treatments using mancozeb were applied at weekly intervals, starting from the onset of first symptoms till vine kill, resulting in 10 to $12 \mathrm{~EB}$ treatments per growing season. In addition, field trials included variants with weekly fungicide treatments of azoxystrobin in order to determine the sitespecific yield potential. To prevent the development of LB, the fungicide Ranman (cyazofamid at $400 \mathrm{~g} \mathrm{liter}^{-1}$ ) was applied as a cover spray at a dose of $0.21 \mathrm{ha}^{-1}$ every 8 to 10 days. The disease progress of EB was not affected by the use of Ranman $(\mathrm{H}$. Hausladen, unpublished data); therefore, EB was allowed to develop naturally during the course of the growing season. All fungicides were applied with a portable overhead backpack sprayer, using air-mix nozzles (Lechler, air-mix 110-0.4) at a pressure of $190 \mathrm{kPa}$. The respective fungicides were sprayed in a water volume equivalent to 400 liters $\mathrm{ha}^{-1}$ and did not contain any additional spreader, sticker, or adjuvant.

Disease rating. Disease progress was observed weekly from potato emergence until the death of the potato plant. In each of the replications, 10 plants per plot were monitored for disease progress of $\mathrm{EB}$ or other diseases (e.g., LB). For the ratings, each potato plant was divided into three levels (lower, middle, and upper leaf section) in order to follow disease development. For each leaf level, one leaflet was examined to determine the percentage of necrotic leaf area. A simplified scheme for the evaluation of leaf necrosis is shown in Figure 1. The disease severity per plant was calculated as a mean value. For leaves which were completely dead or where the lower leaves had senesced and dropped from the

Table 1. Timing and rates for field operations associated with fungicide trials conducted to control early blight in Straubing, Germany ${ }^{\mathrm{a}}$

\begin{tabular}{|c|c|c|c|}
\hline Field operations & Field trial 2005 & Field trial 2006 & Field trial 2007 \\
\hline Cultivar & Kuras & Kuras & Kuras \\
\hline Sowing date & 11 April & 21 April & 31 March \\
\hline Sowing rate & 40,000 tubers $\mathrm{ha}^{-1}$ & 40,000 tubers $\mathrm{ha}^{-1}$ & 40,000 tubers $\mathrm{ha}^{-1}$ \\
\hline Emergence & 17 May & 18 May & 1 May \\
\hline Flowering (EC65) & 1 July & 10 July & 25 June \\
\hline Harvest & 1 October & 1 October & 22 September \\
\hline Fertilizer application date & 18 April & 5 May & 14 April \\
\hline Fertilizer rate & $\mathrm{KAS}, \mathrm{N}$ at $120 \mathrm{~kg} \mathrm{ha}^{-1}$ & $\mathrm{KAS}, \mathrm{N}$ at $120 \mathrm{~kg} \mathrm{ha}^{-1}$ & $\mathrm{KAS}, \mathrm{N}$ at $120 \mathrm{~kg} \mathrm{ha}^{-1}$ \\
\hline Herbicide application date & 13 May & 17 May & 11 May \\
\hline Herbicide rate & $\begin{array}{l}\text { Boxer at } 4 \text { liter ha-1, } \\
\text { Sencor WG at } 0.5 \text { liter ha }{ }^{-1}\end{array}$ & $\begin{array}{l}\text { Boxer at } 4 \text { liter ha }{ }^{-1} \text {, } \\
\text { Sencor WG at } 0.5 \text { liter ha }{ }^{-1}\end{array}$ & $\begin{array}{l}\text { Cato at } 0.25 \text { liter ha-1, } \\
\text { Sencor WG at } 0.4 \text { liter ha }{ }^{-1}\end{array}$ \\
\hline Insecticide application & $\begin{array}{l}18 \text { June, Karate Zeon at } 75 \mathrm{ml} \mathrm{ha}^{-1} \\
28 \text { June, Karate Zeon at } 75 \mathrm{ml} \mathrm{ha}^{-1} \\
\text { 29July, Dantop at } 35 \mathrm{~g} \mathrm{ha}^{-1}\end{array}$ & $\begin{array}{l}16 \text { June, Dantop at } 35 \mathrm{~g} \mathrm{ha}^{-1} \\
2 \text { July, Dantop at } 35 \mathrm{~g} \mathrm{ha}^{-1} \\
\ldots\end{array}$ & $\begin{array}{l}4 \text { June, Dantop at } 35 \mathrm{~g} \mathrm{ha}^{-1} \\
20 \text { June, Dantop at } 35 \mathrm{~g} \mathrm{ha}^{-1} \\
\ldots\end{array}$ \\
\hline
\end{tabular}

\footnotetext{
${ }^{a}$ Treatments: KAS = calcium ammonium nitrate $(27 \% \mathrm{~N})$, Boxer = prosulfocarb $(800 \mathrm{~g} / \mathrm{liter})$, Sencor WG $=$ metribuzin $(700 \mathrm{~g} / \mathrm{kg})$, Cato $=$ rimsulfuron $(250$
} $\mathrm{g} / \mathrm{kg})$, Karate Zeon = lambda-cyhalothrin $(100 \mathrm{~g} / \mathrm{liter})$, and Dantop = clothianidin $(500 \mathrm{~g} / \mathrm{kg})$. 
plant, the disease value of the last possible leaf scoring was used for calculation. At the end of the season, severity values were plotted against time and the area under disease progress curve (AUDPC) was calculated for each treatment. The height of AUDPC values, which reflected the intensity of the EB epidemic, was used to assess the individual control thresholds. AUDPC was calculated using the formula $\left.\Sigma_{i<n}\left[\left(R_{i+1}+R_{i}\right) / 2\right)\right]\left(t_{i+1}-t_{i}\right)$, where $R_{i}$ is the disease severity (percent leaf surface blighted) at the $i$ th observation, $t_{i}$ is the time in days since the previous rating at the $i$ th observation, and $n$ is the total number of observations (34).

Tuber yield and yield loss assessment. At the end of the season, potato plants were harvested from the two center rows of the plots. Tubers were dug out with a tractor-mounted one-row potato lifter. Tubers of the two center rows of each plot were collected by hand, weighed on site, and the tuber yield per hectare was calculated. Harvested tubers were stored for 4 weeks before the starch content was measured for each replication. The starch yield was calculated as the economically relevant measure for starch potato. The percentage of yield increase between threshold-treated and EB-nontreated (EB control) plots was assessed. Site-specific yield losses were evaluated by comparing the EB nontreated control with treatments applied according to thresholds and healthy controls (weekly fungicide treatments).

Data analysis. Statistical analysis was carried out using the software package SPSS (SPSS Inc.). AUDPC values and yield data were submitted to analysis of variance. Mean values were compared using the Tukey test. The level of probability used in all statistical tests was $P<0.05$.

\section{Results}

Quantifying EB and LB disease pressure. EB was the primary foliar disease in all 3 years of investigation. In plots just treated for control of LB but not for control of EB, heavy EB epidemics occurred in 2005 through 2007. Primary infections occurred on the lower leaf sections, thus leading to inconspicuous disease symptoms. As the season progressed, EB symptoms rapidly increased and spread onto higher leaf levels. In EB controls, the secondary spread of EB was observed in all years starting from the end of July or beginning of August. Disease severity in EB-untreated plots increased from less than 5\% to more than $90 \%$ within 5 weeks. In 2005 and 2007, the EB epidemic set in 14 days earlier than in 2006. In these years, EB totally destroyed potato plants by the beginning of September. In 2006, EB resulted in vine kill in midSeptember. As a consequence, EB-untreated plots had significantly higher AUDPC values than fungicide-treated plots (see below).

Disease progress curves of EB control and completely untreated plots $(\mathrm{EB}+\mathrm{LB}$ control) are presented in Figure 2. In the EB+LB control plots, disease progress was characterized by the occurrence of infections by both $P$. infestans and Alternaria spp. Disease severity of LB mainly increased in 2005. In 2006 and 2007, completely untreated plots had only a few infections by $P$. infestans and

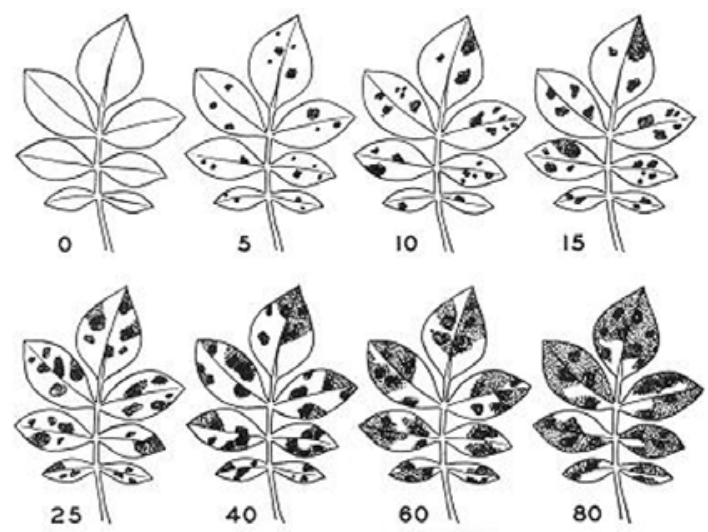

Fig. 1. Schematic chart showing percentages of early blight injury on potato leaves taken from Granovsky and Peterson (15), courtesy of Journal of Economic Entomology. displayed mainly EB symptoms caused by both Alternaria spp. Therefore, only marginal differences in leaf necrosis occurred between disease progress curves of both control treatments in 2006 and 2007.

Evaluation of threshold values on the disease control of EB. Fungicide applications against EB were initiated based on different levels of DI and DS at the entire plant level (p), m.l. level, or u.l. level of plants in the respective plots. Timing for initiating the thresholds is shown in Figure 3. AUDPC values for the corresponding fungicide applications according to the disease-progress-based thresholds are demonstrated in Figure 4. In general, the control of EB significantly improved foliage health in all cases. However, early initial application of fungicides was pivotal for effective disease control and resulted in statistically different levels of effectiveness of EB control.
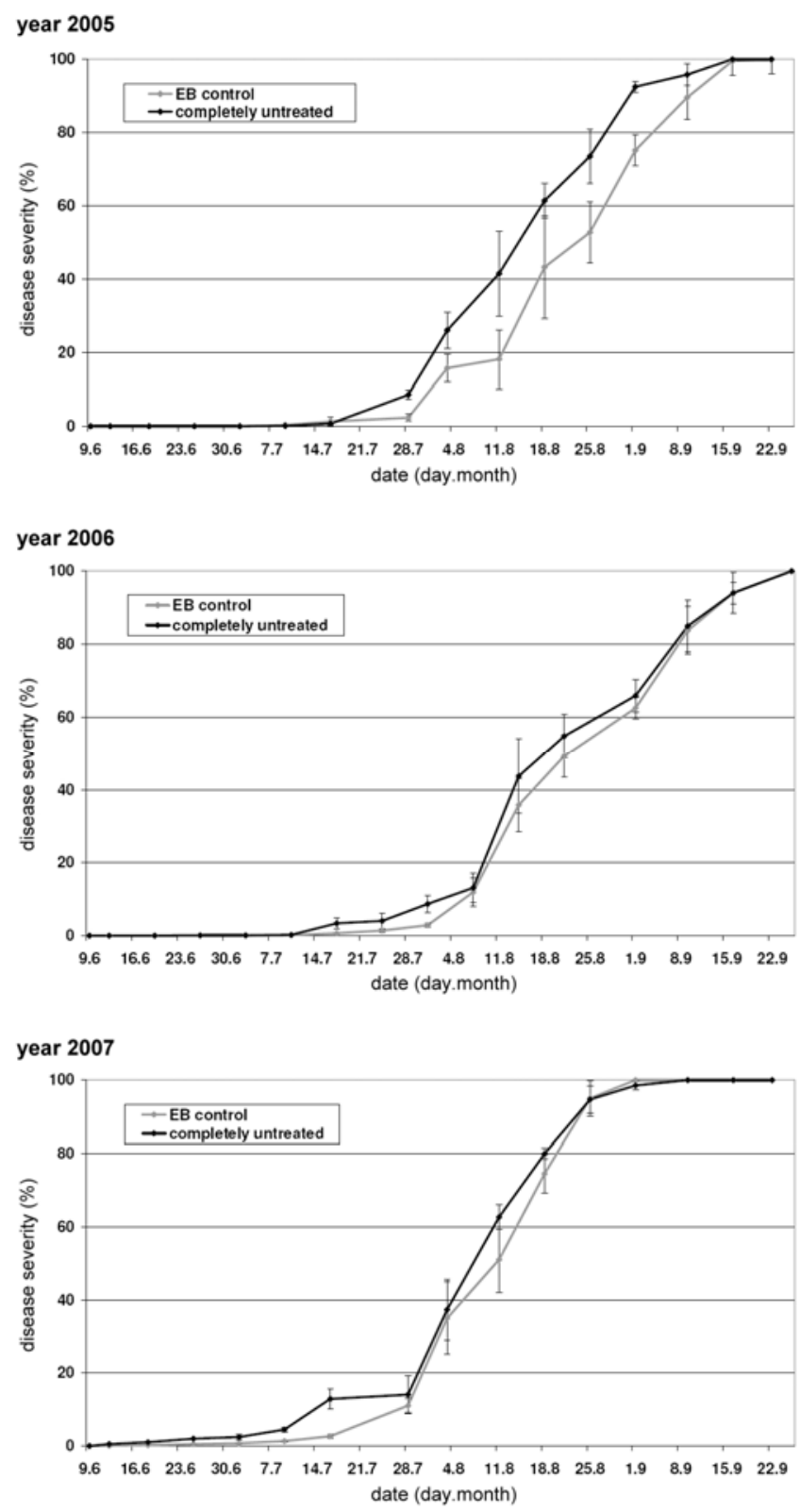

Fig. 2. Disease progress within the early blight (EB) control (which stayed untreated against EB but was protected against late blight [LB]; gray line) and the completely untreated control (EB and LB untreated; black line) for 'Kuras' potato during the 2005-07 growing seasons in Straubing, Germany. LB control was carried out with the fungicide Ranman (cyazofamid at $400 \mathrm{~g} \mathrm{liter}^{-1}$ ) as a cover spray at a dose of 0.2 liter ha ${ }^{-1}$ every 8 to 10 days. Disease severity (percentage of EB or LB) represents the mean value of four repetitions, while the bars represent standard deviations. 
In 2005, fungicide applications were carried out in response to foliar disease beginning at early disease onset $\left(50 \% \mathrm{DI}_{\mathrm{p}}\right)$ until advanced stages of EB disease $\left(25 \% \mathrm{DS}_{\mathrm{p}}\right)$. Applications of azoxystrobin led to a reduction in foliar disease severity and, likewise, to a delayed disease progress. Single treatments with azoxystrobin at early stages of disease progress $\left(50 \% \mathrm{DI}_{\mathrm{p}}\right.$ or $\left.100 \% \mathrm{DI}_{\mathrm{p}}\right)$ significantly reduced leaf blight compared with the untreated EB control. The primary threshold value $\left(50 \% \mathrm{DI}_{\mathrm{p}}\right)$ was already reached 3 weeks after crop emergence (Fig. 3). Almost no differences were detected between AUDPC values when treatments were initiated at 50 or $100 \%$ disease incidence $\left(\mathrm{DI}_{\mathrm{p}}\right)$. In 2005 , fungicide treatments which were applied at more advanced disease levels of $5 \% \mathrm{DS}_{\mathrm{p}}(2$ August) and 25\% DS $\mathrm{p}_{\mathrm{p}}(8$ August) (Fig. 3) reduced final foliar disease severity but were no more effective than treatments which
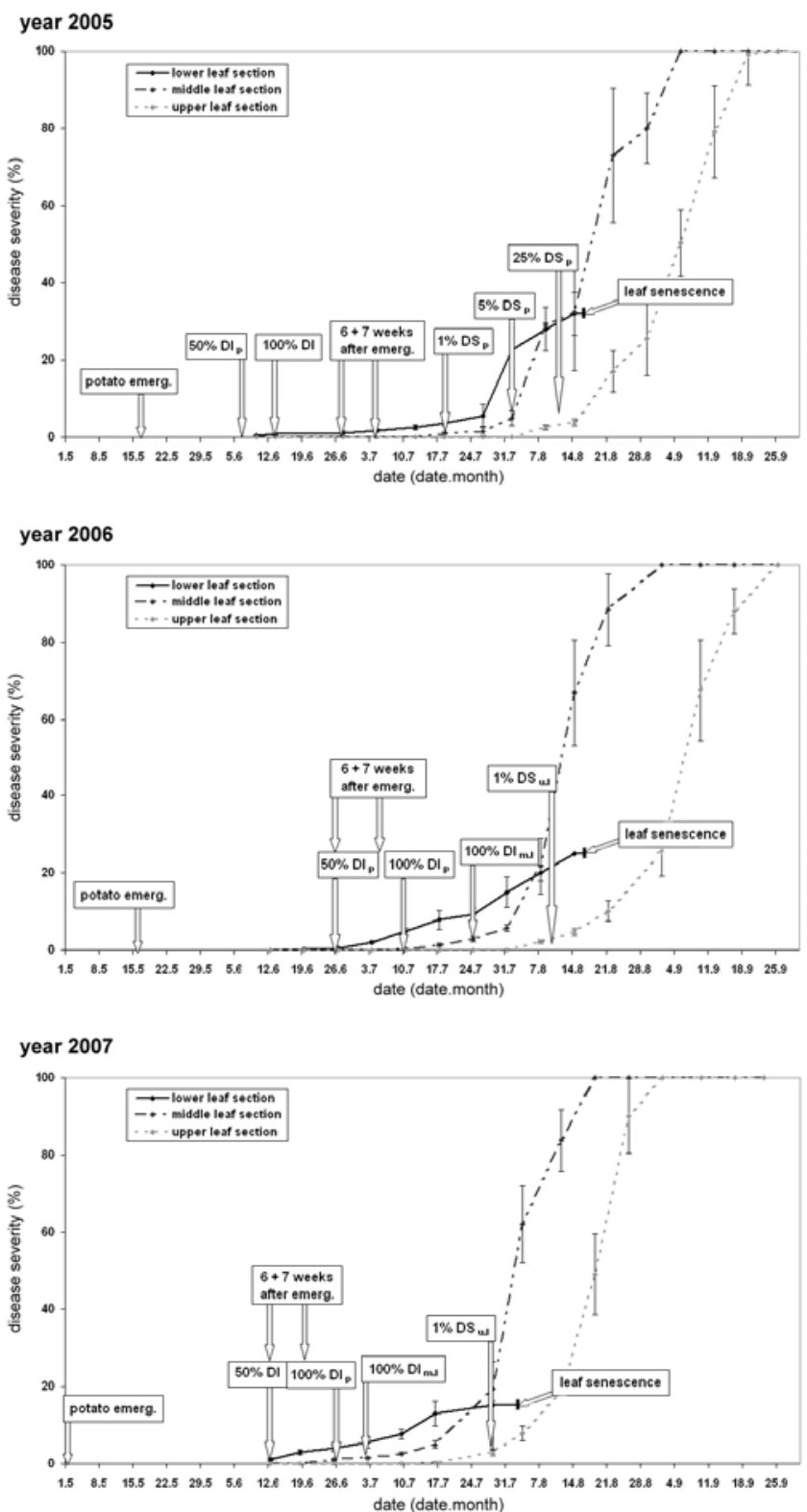

Fig. 3. Achievement of control thresholds and disease progression of early blight (EB) in 'Kuras' potato were established on these dates in 2005-07 at Straubing, Germany. Progress of EB is shown for different leaf sections (lower, middle, and upper leaf sections). Disease severity represents the mean value of four repetitions. Leaves of the lower leaf section showed leaf senescence and were not investigated further. The time of leaf senescence is designated by an arrow. Bars represent standard deviations. $\mathrm{DI}=$ disease incidence, $\mathrm{DS}=$ disease severity, $\mathrm{m} . \mathrm{I}$ = middle leaf and u.l. = upper leaf sections (e.g., $50 \% \mathrm{DI}_{\mathrm{p}}=50 \%$ of plants showing $\mathrm{EB}$ symptoms at any leaf section and $100 \% \mathrm{DI}_{\mathrm{m.l}} .=100 \%$ of plants showing $\mathrm{EB}$ symptoms in the m.l. section). started at earlier stages of disease development (Fig. 4). As a result of this, fungicide sprayings at 5 and $25 \% \mathrm{DS}_{\mathrm{p}}$ threshold level were not investigated in subsequent years.

The use of combined fungicide treatments, which were applied at different disease thresholds, led to further reduction of EB. However, disease was suppressed differently depending on the chosen thresholds for application. Fungicide double treatments, which were applied early $\left(50+100 \% \mathrm{DI}_{\mathrm{p}}\right)$ or late $\left(5+25 \% \mathrm{DS}_{\mathrm{p}}\right)$ in the course of disease progress, resulted in only slightly increased disease control when compared with the single treatments. In 2005, disease development was most effectively controlled by double treatments when EB was first treated at $100 \%$ disease incidence
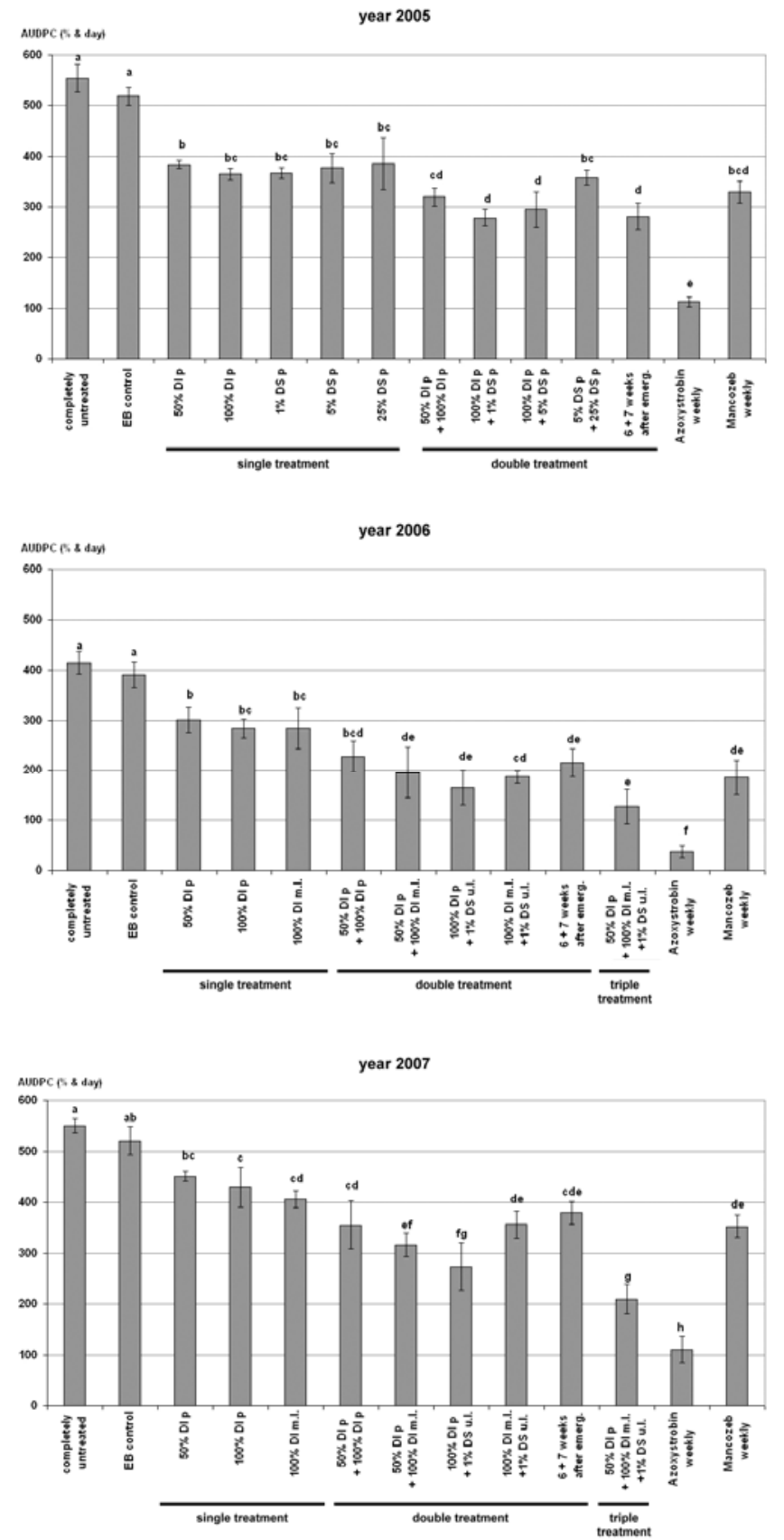

Fig. 4. Expression of early blight area under disease progress curve (AUDPC) values as a function of fungicide treatments at different control thresholds in 'Kuras' potato in 2005-07 at Straubing, Germany. AUDPC values represent the means of four repetitions. Single, double, or triple applications of azoxystrobin $\left(125 \mathrm{~g}\right.$ a.i. $\left.\mathrm{ha}^{-1}\right)$ were conducted at disease thresholds indicated. For explanation of thresholds, see Materials and Methods. Bars represent standard deviations. Significant differences between fungicide treatments at different disease thresholds are represented by different letters $(P<0.05$, Tukey test). $\mathrm{DI}=$ disease incidence, $\mathrm{DS}=$ disease severity, $\mathrm{m} . \mathrm{l} .=$ middle leaf and u.l. $=$ upper leaf sections. 
$\left(100 \% \mathrm{DI}_{\mathrm{p}}\right)$. In 2006 and 2007, EB was also suppressed the most when fungicide treatments were first applied at $100 \% \mathrm{DI}_{\mathrm{p}}$.

In 2006 and 2007, the threshold 1\% DS $\mathrm{p}_{\mathrm{p}}$ was replaced by an alternative threshold value, which was reached at the time when $100 \%$ of the plants showed symptoms on middle leaf sections $\left(100 \% \mathrm{DI}_{\mathrm{m} . \mathrm{l} .}\right)$. Fungicide treatments, which were applied according to the threshold $50 \% \mathrm{DI}_{\mathrm{p}}+100 \% \mathrm{DI}_{\mathrm{m} . \mathrm{l}}$, tended to lead to improved disease control in comparison with the threshold $50 \% \mathrm{DI}_{p}+100 \%$ $\mathrm{DI}_{\mathrm{p}}$. Among the threshold-based applications in 2006 and 2007, triple application of azoxystrobin $\left(50 \% \mathrm{DI}_{\mathrm{p}}+100 \% \mathrm{DI}_{\mathrm{m} . \mathrm{l}}+1 \%\right.$ $\mathrm{DS}_{\mathrm{u.l.}}$ ) against $\mathrm{EB}$ was more effective than double treatments but not as effective as weekly treatments applied throughout the season (Fig. 4). Weekly applications most effectively controlled EB based on symptoms, although EB was not completely suppressed.
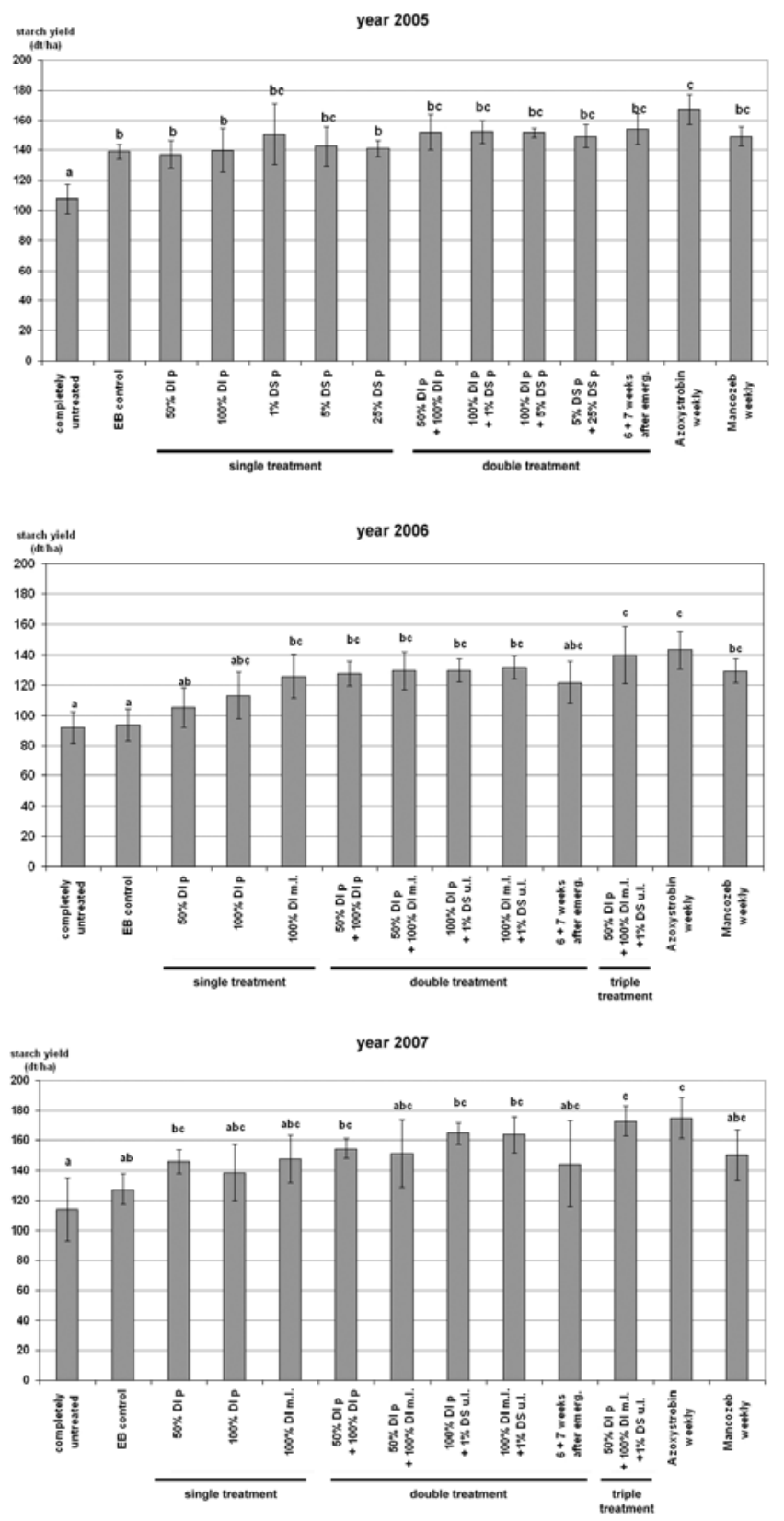

Fig. 5. Comparison of starch yields as a function of fungicide treatments at different early blight control thresholds in 'Kuras' potato in 2005-07 at Straubing, Germany. Data are the mean values of four repetitions. Single, double, or triple applications of azoxystrobin (125 g a.i. ha-1 ${ }^{-1}$ were conducted at disease thresholds indicated. For an explanation of thresholds, see Materials and Methods. Bars represent standard deviations. Significant differences between fungicide treatments at different disease thresholds are represented by different letters $(P<0.05$, Tukey test). $\mathrm{DI}=$ disease incidence, $\mathrm{DS}=$ disease severity, $\mathrm{m} . \mathrm{I} .=$ middle leaf and u.I. = upper leaf layers.
The use of fungicides with different modes of action had strong influence on the AUDPC. Although weekly treatments with mancozeb led to a reduced disease severity of $\mathrm{EB}$, it was not able to reach the disease control of azoxystrobin (Fig. 4). Just two threshold-based applications with azoxystrobin showed disease control similar to that of mancozeb when applied weekly. Efficiency of disease control was dependent on the spray timing and the number of fungicide applications.

Threshold values based on certain stages of disease development were highly effective in controlling EB. The effect of the time of spray initiation and subsequent fungicide application could clearly be seen throughout the years. The adaptation of disease control according to leaf section-specific thresholds in 2006 and 2007 enabled further improvement of EB control. Mainly, those thresholds achieved satisfying EB control and were initiated before disease onset or at only marginal disease severities at the specific leaf levels. Two to three disease-orientated fungicide applications already resulted in a significant reduction in disease severity. Here, applications of fungicides according to EB development were able to achieve adequate disease control and to reduce the number of sprayings compared with unspecific treatments.

Yield assessment. The estimation of potato yield showed that control of EB resulted in increase of starch yield ranging from 0 to $54 \%$, when compared with EB-untreated plots. According to AUDPC data, most fungicide treatments suppressed foliar blight compared with the EB-untreated plots. However, timing of treatments was crucial for the achievement of high starch yields (Fig. 5). In accordance with the results of the disease ratings, the fully untreated control $(\mathrm{EB}+\mathrm{LB}$ control) generated the lowest yield over all years because of simultaneous infections with $P$. infestans and Alternaria spp. Similarly, yields of EB-untreated plots were significantly reduced by 10 to $30 \%$ in the years under investigation when compared with plots subjected to fungicide treatments. Single EB treatments in 2005 did not result in significant yield increase. Starch yield was approximately at the same level for single treatments at most of the investigated thresholds $\left(50 \% \mathrm{DI}_{\mathrm{p}}, 100 \%\right.$ $\mathrm{DI}_{\mathrm{p}}, 5 \% \mathrm{DS}_{\mathrm{p}}$, and $25 \% \mathrm{DS}_{\mathrm{p}}$ ). Only the threshold $1 \% \mathrm{DS}_{\mathrm{p}}$ led to a tendency for higher starch yield. The low efficacy of single treatments may be explained by the narrow dynamic range of yield losses caused by EB in 2005 (note the relatively high yield in EB control). Double-fungicide treatments with azoxystrobin resulted in a general tendency toward higher starch yields compared with single applications. However, in 2005, starch yield was only significantly increased when azoxystrobin was applied at weekly intervals (Fig. 5). Treatment with azoxystrobin at weekly intervals generated the highest starch yield in all years. Distinct differences in potato starch yield depending on threshold-based fungicide applications were observed in 2006 and 2007. Among the single treatments over both years, the application at the threshold $100 \%$ $\mathrm{DI}_{\mathrm{m} . \mathrm{l}}$ resulted in the highest yield. When azoxystrobin was applied twice, treatments resulting in particularly increased yield were those applied at thresholds $100 \% \mathrm{DI}_{\mathrm{p}}$ or $100 \% \mathrm{DI}_{\mathrm{m} . \mathrm{l}}$ and $1 \% \mathrm{DS}_{\mathrm{u} .1 .}$. However, in comparison with the EB-untreated plots, these differences were only statistically significant in 2006. Triple applications of azoxystrobin at disease threshold $50 \% \mathrm{DI}_{\mathrm{p}}+100 \% \mathrm{DI}_{\mathrm{m} . \mathrm{l}}+1 \%$ $\mathrm{DS}_{\text {u.l. }}$ allowed for high starch yields that were similar to those reached after weekly application of the fungicide. In contrast, applications which were carried out at fixed time points independently of disease progress ( 6 and 7 weeks after crop emergence) were not significantly different from EB-untreated controls or weekly treatments with mancozeb. The data show that the timing of fungicide treatments influenced progress of EB as well as yield. Fungicide applications, which were not adapted to actual disease development, tended to result in lower starch yields. An increase in starch yield was especially evident after application at thresholds which also reduced AUDPCs according to lower disease severity of EB.

\section{Discussion}

Investigations of disease progress demonstrated the importance of fungicide use for the control of EB in the production of potato. 
Depending on the application frequency of specific EB fungicides and the control threshold used, increase of starch yield varied between 0 and 54\%, when compared with EB-untreated plots. Ineffective EB control induced leaf necrosis, which resulted in reduced green leaf area and premature defoliation. The primary objective of this study was to develop an effective integrated pest management strategy against EB in potato, based on data from field trials. This study examined the use of disease progress thresholds as criteria for timing of fungicide applications because disease thresholds can be important tools for farmers to reduce disease epidemics. Threshold-based control strategies have already been developed for fungal diseases on a number of crops $(3,42,43)$. In this work, different threshold values were tested for controlling EB in potato in three consecutive years. Based on these investigations, significant differences in EB control were established as a function of implemented threshold values and the frequency of fungicide application.

Harrison et al. (17) already indicated that the timing of the initial fungicide application is particularly important for improving the effectiveness of EB control. In our trials, AUDPCs tended to show lower values over all years if first applications were carried out at low thresholds of $1 \% \mathrm{DS}_{\mathrm{p}}$ or $100 \% \mathrm{DI}_{\mathrm{m} .1 \text {. }}$. Rotem (32) suggested that the first fungicide application should take place before secondary spread of the pathogen. For managing Alternaria leaf blight in carrot, Gillespie and Sutton (14) delayed the initial fungicide application in carrot until 1 to $2 \%$ of the leaf area developed symptoms. Delayed application allowed the omission of several fungicide treatments without compromising disease control or yield. Our results show that treatments beginning when EB infections first appeared resulted in reduced EB disease. However, Douglas and Groskopp (11) reported that treatments related to secondary invasion of the pathogen were highly effective. According to Rotem (32), secondary infections occurred when spores from primary lesions were spread to healthy leaves. Based on our investigations, the disease thresholds $100 \% \mathrm{DI}_{\mathrm{m} . \mathrm{l}}$ and $1 \% \mathrm{DS}_{\mathrm{u} . \mathrm{l}}$ mark an important threshold for fungicide application. Disease ratings from EBuntreated plots documented an exponential development of disease severity 10 to 14 days after onset of these threshold values (Fig. 3).

In 2006 and 2007, the threshold value $1 \% \mathrm{DS}_{\mathrm{p}}$ was replaced by the threshold $100 \% \mathrm{DI}_{\mathrm{m} .1 .}$. This resulted in the lowest AUDPC values among single treatments although differences from other single treatments were not statistically significant. According to Prasad and Dutt (28), disease observation of leaves from the middle of the haulms simplified disease ratings because basal leaves soon became yellow and collapsed. Christ (8) also pointed out that leaves from the middle third of the stem led to the most consistent results in regard to disease assessment. In 2005, fungicide sprayings initiated at 5 or $25 \%$ disease severity $\left(5\right.$ or $25 \% \mathrm{DS}_{\mathrm{p}}$ ) were not more effective when compared with earlier treatments $\left(50 \% \mathrm{DI}_{\mathrm{p}}, 100 \%\right.$ $\mathrm{DI}_{\mathrm{p}}$, or $1 \% \mathrm{DS}_{\mathrm{p}}$ ) and resulted in starch yield similar to EBuntreated plots. Fungicides apparently did not provide improved control when application was delayed because the disease was already established in the crop. Similar observations were made by Rosenzweig et al. (31), who delineated that QoI fungicides such as azoxystrobin should not be used as a curative treatment. Recent investigations showed that products with strong protective activity (e.g., azoxystrobin) were more effective when applied earlier in disease control strategies (21).

EB disease development followed a gradual upward progression in the 3 years of trials; therefore, fungicide sprays should be recommended at early stages of the disease because most of the inoculum for infection of the upper leaves is likely to be formed on lower leaves. Our data indicate that proper timing of initial treatments may be of importance. However, because EB is characterized by polycyclic development capable of exponential multiplication, more than a single treatment was required for effective disease control. Fungicide applications, which were carried out early but were not followed by consecutive applications, were not effective in regard to protection of yield when compared with EBuntreated plots. Hence, it is recommended that developing parts of the plant are protected from secondary inoculum by second or third fungicide applications, which can also be based on disease thresholds. Accordingly, the highest yield increase was achieved by additional applications, which lowered the risk of further progression of EB and yield losses. In this context, the threshold $1 \% \mathrm{DS}_{\mathrm{u} .1 .}$. proved important for optimizing fungicide application against EB. The lowest AUDPC values over the 2 years were observed when fungicides were applied at the threshold of $100 \% \mathrm{DI}_{\mathrm{p}}+1 \% \mathrm{DS}_{\mathrm{u} . \mathrm{l}}$. Our experiments showed that fungicide treatment frequencies can be reduced and adapted to the type of epidemic, provided that fungicide treatments are carried out at pivotal times in the epidemic. Marked differences were also observed in the control of EB disease due to the effectiveness of the active ingredients applied. Weekly applications of azoxystrobin led to significantly reduced AUDPC values compared with mancozeb.

In contrast, calendar-based and "late-initiation" methods, which were conducted at disease severities higher than $10 \%$, were less effective in limiting EB. Plant development-based treatments resulted in AUDPC values comparable with threshold-based treatments only in years in which they coincided with the time of secondary infection onset (e.g., 2005). In accordance with our results, Ben-Noon et al. (2) emphasized the importance of early sprays in the overall suppression of Alternaria leaf blight in carrot because early sprays prevent the first disease cycles and delayed the establishment of the pathogen in the crop.

Weekly fungicide treatments of azoxystrobin, which were established in order to determine the site-specific yield potential, resulted in the lowest AUDPC values. In addition to weekly treatments, three threshold-based fungicide applications resulted in the lowest AUDPC value and led to almost the same yield. The prevention of leaf infections apparently resulted in effective disease control and yield increase. Similarly, Rosenzweig et al. (31) found no additional benefit in disease control with more than three applications of azoxystrobin.

According to Rotem (32), yield loss caused by EB results from the destruction of foliage which, in turn, reduces assimilates accumulated in the tubers. Shtienberg et al. (36) as well as Hide and Lapwood (20) presumed that the tuber-filling process stops when defoliation reaches $75 \%$, and considered this value to be the critical point for yield loss. Douglas and Groskopp (11) deduced that the prevention of EB on leaves of the upper two-thirds of the plant seems to be of particular importance for protecting yield, which is in concordance with our results.

Adequate EB control prolonged green leaf area, as was evident by a reduction in AUPDC values, which likely explains the increase in starch yield. Also, Horsfield et al. (21) suggested that longer maintenance of green leaf area increases the period of tuber bulking and yield. Profitable potato production demands high yields and quality to allow for high starch yields and stable starch contents. Using disease-orientated thresholds, yield was significantly increased over all years, provided that applications were initiated before disease onset or at only marginal disease severities. When comparing the EB control plots with plots treated three times with azoxystrobin, starch yield was increased by an average of $4.6 \mathrm{t} / \mathrm{ha}(+41 \%)$ in 2006 and 2007 . Given that the average (years 2001 to 2010) minimum price for a ton of starch guaranteed by the European Union was $39.8 € / \mathrm{t}$ in addition to government support of $14.8 € / \mathrm{t}$ (1) and one fungicide application was $35 € /$ ha $(25 € /$ ha for product and $10 € /$ ha for spraying), EB control generated a net profit of $150 € /$ ha. This would mean that the benefit from applying azoxystrobin three times would be twice the costs for the sprays.

Minimizing the number of applications of a particular fungicide is one of the most effective ways to reduce the risk of fungicide resistance $(5,31)$. Fungicide resistance as well as reduced sensitivity has become increasingly important, especially for fungicides with single-site mode of actions such as strobilurines. Pasche et al. (26) reported that field isolates of $A$. solani, which were sampled throughout the United States, possessed reduced sensitivity against azoxystrobin. According to them, EB control in the United States depends primarily on multiple, typically weekly, fungicide applica- 
tions. Failure of EB control was predominantly observed for potato fields, where the EB fungus was exposed to numerous applications (10 to 12) and where applications were carried out during periods with extremely high EB disease pressure. Rosenzweig et al. (31) already recognized the need for practical fungicide resistance management strategies for the control of $\mathrm{EB}$ in potato and for the continued effectiveness of azoxystrobin. The implementation of threshold values tested here may help to control EB with a maximum of three applications, thus avoiding redundant applications. Due to the reduced number of azoxystrobin applications, the selection pressure on A. solani would also be reduced. Depending on the investigated disease thresholds, EB control can be achieved in a protective way because applications are carried out at relatively low levels of disease manifestation. As a result of this, EB is controlled early in the season. To prevent an uncontrolled increase in EB disease or an epidemic, follow-up treatments are tailored according to the specific pathogen development on the plant. According to our investigations, the consideration and suppression of the EB development on the m.l. and u.l. levels are important characteristics for successful EB control. These implementations would fulfill the requirements of Rosenzweig et al. (31), who already postulated that, to limit the total number of sprays, EB must be controlled early in the growing season.

The goal of the present study was to optimize the use of fungicide application for the suppression of EB in potato. Specific objectives were to identify the optimal timing to control EB and to develop a disease management system which can be adapted to the specific pathogen threat in the field. Little is known about the efficacy of control threshold values for suppressing potato EB. Results indicate that it is not necessary to apply EB control throughout the season. EB disease in potato can be adequately controlled with only a few fungicide applications, using threshold values based on disease progress.

\section{Acknowledgments} script.

We thank R. Hückelhoven and R. Eichmann for critical reading of the manu-

\section{Literature Cited}

1. Anonymous, 2003. Commission regulation (EC) no. 2235/2003 of 23. December 2003. Laying down common rules for the application of Council Regulations (EC) no. 1782/2003 and (EC) no. 1868/94 as regards potato starch. Off. J. Eur. Union L 229:36-44.

2. Ben-Noon, E., Shtienberg, D., Shlevin, E., and Vintal, H. 2001. Optimization of chemical suppression of Alternaria dauci, the causal agent of Alternaria leaf blight in carrots. Plant Dis. 85:1149-1156.

3. Bounds, R. S., Podolsky, R. H., and Hausbeck, M. K. 2007. Integrating disease thresholds with TOM-Cast for carrot foliar blight management. Plant Dis. 91:798-804.

4. Bouwman, J. J., and Rijkers, G. 2004. The control of Alternaria solani (early blight) with azoxystrobin in potatoes. Pages 179-188 in: PPO Spec. Rep. No. 10. C. E. Westerdijk, and H. T. A. M. Schepers, eds. (HRSG) Applied Plant Research BV, Wageningen, The Netherlands.

5. Brent, K. J., and Hollomon D. W. 2007. Fungicide resistance in crop pathogens-how it can be managed? Fungicide Resistance Action Committee, Crop Life International, Brussels.

6. Campo Arana, R. O., Zambolim L, and Costa, L. C. 2007. Potato early blight epidemics and comparison of methods to determine its initial symptoms in a potato field. Rev. Fac. Nac. Agron. Medellin Colomb. 60-2:38773890.

7. Christ, B. J. 1990. Influence of potato cultivars on the effectiveness of fungicide control of early blight. Am. Potato J. 67:419-425.

8. Christ, B. J. 1991. Effect of disease assessment method on ranking potato cultivars for resistance to early blight. Plant Dis. 75:353-356.

9. Christ, B. J., and Maczuga, S. A. 1989. The effect of fungicide schedules and inoculum levels on early blight severity and yield of potato. Plant Dis. 73:695-698.

10. Dita Rodriguez, M. A., Brommonschenkel, S. H., Matusuoka, K., and Mizubuti, E. S. G. 2006. Components of resistance to early blight in four potato cultivars: effect of leaf position. J. Phytopathol. 154:230-235.

11. Douglas, D., and Groskopp, M. 1974. Control of early blight in eastern and south-central Idaho. Am. Potato J. 51:361-367.

12. Franc, G. D., Harrison, M. D., and Lahman, L. K. 1988. A simple day-degree model for initiating chemical control of potato early blight in Colorado. Plant Dis. 72:851-854.

13. Gent, D. H., and Schwartz, H. F. 2003. Validation of potato early blight disease forecast models for Colorado using various sources of meteorologi- cal data. Plant Dis. 87:78-84

14. Gillespie, T. J., and Sutton, J. C. 1979. A predictive scheme for timing fungicide application to control Alternaria leaf blight in carrots. Can. J. Plant Pathol. 1:95-99.

15. Granovsky, A. A., and Peterson, A. G. 1954. Evaluation of potato injury caused by leafhoppers, flea Beetles, and early blight. J. Econ. Entomol. 47:894-902.

16. Hadders, J. 2003. Control of early blight (Alternaria) with PLANT-Plus. Pages 95-104 in: PPO Spec. Rep. No. 9. Lelystad, The Netherlands.

17. Harrison, M. D., Livingstone, C. H., and Oshima, N. 1965. Control of potato early blight in Colorado. I. Fungicidal spray schedules in relation to the epidemiology of the disease. Am. Potato J. 42:319-327.

18. Harrison, M. D., and Venette, J. R. 1970. Chemical control of potato early blight and its effect on potato yield. Am. Potato J. 47:81-86.

19. Hausladen, H. 2006. Potato early blight (Alternaria spp.) in Germany. Pages 313-318 in: PPO Spec. Rep. No. 11. C. E. Westerdijk and H. T. A. M. Schepers, eds. (HRSG) Applied Plant Research BV, Wageningen, The Netherlands.

20. Hide, G. A., and Lapwood, D. H. 1992: Disease aspects of potato production. Pages 403-437 in: The Potato Crop-The Scientific Basis for Improvement. P. M. Harris, ed. Chapman and Hall, London.

21. Horsfield, A., Wicks, T., Davies, K., Wilson D., and Paton, S. 2010. Effect of fungicide use strategies on the control of early blight (Alternaria solani) and potato yield. Austral. Plant Pathol. 39:368-375.

22. Johnson, K. B., Radcliffe, E. B., and Teng, P. S. 1986. Effects of interacting populations of Alternaria solani, Verticillium dahliae, and the potato leafhopper (Empoasca fabea) on potato yield. Phytopathology 76:10461052.

23. Leiminger, J. H. 2009. Alternaria spp. an Kartoffeln-Empirische Untersuchungen zur Epidemiologie, Schadrelevanz und integrierten Bekämpfungsstrategien, Ph.D. thesis, Technische Universität München, Druck und Verlag H. Hieronymus, München.

24. McKenzie, D. 1991. Vroeëroes, 'n onderskatte siekte op aartappels in Suid Afrika. Pages 7-10 in: Potato Course, Vegetable and Ornamental. Plant Research Institute, Agricultural Research Council, Roodeplaat, South Africa.

25. Nadia, G. E, Abd-El-Kareem, F., Fotouh, Y. O., and Nehal, S. E. 2007. Induction of systemic resistance in potato against late and early blight diseases using chemical inducers under greenhouse and field conditions. Res. J. Agric. Biol. Sci. 3:73-81.

26. Pasche, J. S., Wharam, C. M., and Gudmestad, N. C. 2004. Shift in sensitivity of Alternaria solani in response to $\mathrm{Q}_{\mathrm{o}} \mathrm{I}$-fungicides. Plant Dis. 88:181-187.

27. Pelletier, J. R., and Fry, W. E. 1990. Characterization of resistance to early blight in three potato cultivars: receptivity. Phytopathology 80:361-366.

28. Prasad, B., and Dutt, B. L. 1971. Laboratory assessment of the reaction of potato varieties to Alternaria solani. Indian J.Microbiol.11:91-96.

29. Pscheidt, J. W. 1985. Epidemiology and control of potato early blight, caused by Alternaria solani. Ph. D. thesis, University of Wisconsin, Madison.

30. Reifschneider, F. J. B., Lopez, C. A., and Cobbe, R. V. 1989. Manejo integrado das doenças da batata. Circ. Téc. 7, EMBRAPA Hortaliças, Brasília.

31. Rosenzweig, N., Atallah, Z. K., and Stevenson, W. R. 2008. Evaluation of QoI fungicide application strategies for managing fungicide resistance and potato early blight epidemics in Wisconsin. Plant Dis. 92:561-568.

32. Rotem, J. 1994. The Genus Alternaria: Biology and Pathogenicity. American Phytopathological Society, St. Paul, MN

33. Secor, G. A., and Gudmestad, N. C. 1999. Managing of fungal diseases of potato. Can. J. Plant Pathol. 21:213-221.

34. Shaner, G., and Finney, R. E. 1977. The effect of nitrogen fertilization on the expression of slow-mildewing resistance in Knox wheat. Phytopathology 67:1051-1056.

35. Shtienberg, D. 2001. Integrated management of early and late blights of potatoes in Israel. Afr. Crop Sci. J. 9:203-207.

36. Shtienberg, D., Bergeron, S. N., Nicholson, A. G., Fry, W. E., and Ewing, E. E. 1990: Development and evaluation of a general model for yield loss assessment in potatoes. Phytopathology 80:466-472.

37. Shtienberg, D., Doster, M. A., Pelletier, J. R., and Fry, W. E. 1989. Use of simulation models to develop a low risk strategy to suppress early and late blight in potato foliage. Phytopathology 79:590-595.

38. Shtienberg, D., and Fry, W. E. 1990. Influence of host resistance and crop rotation on initial appearance of potato early blight. Plant Dis. 74:849-852.

39. Sinden, S. L., Goth, R. W., and O'Brien, M. J. 1973. Effect of potato alkaloids on the growth of Alternaria solani and their possible role as resistance factors in potatoes. Phytopathology 63:303-307.

40. Stevenson, W. 1993. Management of early and late blight. Pages 141-147 in: Potato Health Management. R. C. Rowe, ed. The American Phytopathological Society. St. Paul, MN.

41. Statistisches Jahrbuch. 2010. Herausgeber Statistisches Bundesamt (Federal Statistical Office) Wiesbaden. Bonifatius GmbH, Druck-Buch-Verlag, Paderborn, Germany.

42. Verreet, J.-A., and Hoffmann, G. M. 1990. A biologically oriented threshold decision model for control of epidemics of Septoria nodorum in wheat Plant Dis. 74:731-738.

43. Wolf, P. F. J., Weis, F.-J., and Verreet, J.-A. 2001. Threshold values as indicators of fungicide treatments for the control of leaf blotching caused by Cercospora beticola (Sacc.) in sugar beets. J. Plant Dis. Prot. 108:244-257. 